\title{
Theories of Learning as Theories of Society: A Contrapuntal Approach to Expanding Disciplinary Authenticity in Computing
}

\author{
Thomas Philip \\ University of California, Berkeley \\ tmp@berkeley.edu \\ Pratim Sengupta \\ University of Calgary \\ pratim.sengupta@ucalgary.ca
}

September 15, 2020

\begin{abstract}
Background

We outline a case for how the Learning Sciences is at a powerful inflection point where the "real world" needs to be seen as comprised of the political entities and processes in which learning happens. We seek to sharpen the principle that learning is political by elucidating historical and contemporary processes of European and U.S. imperialism that remain foundational to our field and developing the argument that theories of learning are theories of society.
\end{abstract}

\section{Methods}

Through a contrapuntal approach, which emphasizes a critical lens to analyze empire, we juxtapose notions of authentic practice in computing education with scholarship in sociology that brings the lives of tech industry immigrant workers to the fore.

\section{Findings}

Our analysis reveals how the social construction of disciplinary and professional expertise in computing is intricately interwoven with historically persistent patterns of the appropriation of lives and labor of endarkened people through systems of transnational migration and institutional forms of racial segregation.

\section{Contributions}

A contrapuntal lens in the learning sciences prompts our field to embrace the necessary uncertainties and the theoretical and methodological possi- 
bilities that emerge when sites of learning and learning itself are recognized as political and as contestations of empire.

Starting in the 1990s, the Learning Sciences broke ranks with conventional educational psychology research with its commitment to "interdisciplinary empirical investigation of learning as it exists in real-world settings" (International Society of the Learning Sciences, n.d.). The burgeoning field was premised on the need to study learning in situ coupled with explicit attention to design. This move came with its own challenges, particularly critiques that the designoriented approach to researching learning in real-world settings lacked scientific rigor, replicability, and generalizability (Shavelson, Phillips, Towne, \& Feuer, 2003). Building a paradigmatic response that argued for ecological validity has been a slow, unfolding process (Cobb, Confrey, diSessa, Lehrer, Schauble, 2003; Fishman, Penuel, Allen, Cheng, \& Sabelli, 2013; Sandoval, 2014). As a field, we are at a parallel inflection point today. Increasingly, researchers in the Learning Sciences are showing that studying learning in real-world settings entails understanding learning as political (Booker, Vossoughi, \& Hooper, 2014; McKinney de Royston \& Sengupta-Irving, 2019; Philip, Bang, \& Jackson, 2018; The Politics of Learning Writing Collective, 2017). From this perspective, the political nature of the "real world" and the learning within it are inseparable. Honoring the distinctive roots of the Learning Sciences to investigate learning in the complexities and fullness of the real world, we argue that the field is at another crucial juncture that requires grappling with the theoretical and methodological uncertainties and possibilities that emerge when sites of learning and learning itself are recognized as political and as potential contestations of empire. We take this argument a step further and make the case that in order for the field to productively address the most compelling issues of learning today, it needs to work from the premise that theories of learning are implicit theories of society. In doing so, we further emphasize the need to attend to the lens of imperialism in our analysis of learning.

\section{Theories of Learning as Theories of Society}

We seek to sharpen the principle that learning is political by examining the relationship between theories of learning and theories of society (see Philip, 2019). As a field, we must do more to understand theories of learning as emergent within the contradictions and tensions of researchers' cultural and sociopolitical contexts; these theories of learning must also be seen in light of the worlds they in turn co-construct. We examine the contemporary contexts and openings in the field to argue for an approach to the Learning Sciences that takes a more expansive lens to human learning and the political possibilities it entails.

There are distinct sociopolitical consequences that result from the trend in the Learning Sciences to treat theories of learning through a romanticized nar- 
rative of scientific progression. It is not unusual for an introductory course on learning to march through behaviorism, cognitivism, and sociocultural theory with such a view - at least implicitly conveying to novices that obsolete theories are discarded as the science progresses. More seasoned views of the field tend to agree that "theories concerning educational matters seem to replace one another, rather than subsume, extend, or complement other theories" (disessa \& Cobb, 2004, p. 79). Yet, even these perspectives do not account for the sociopolitical processes that lead to some theories thriving and others perishing. The most prevalent approaches to socializing new scholars into the Learning Sciences glosses over and silences the inherent sociopolitical contexts and consequences in which theories of learning have emerged, flourished, or languished. We recognize that while individual experiences in a broad and diverse area like the Learning Sciences will certainly vary, the peripherality of socio-politics in the field is evidenced by its nonexistence in major reviews of Learning Sciences programs (Nathan, Rummel, \& Hay, 2016; Packer \& Maddox, 2016; Sommerhoff, Szameitat, Vogel, Chernikova, Loderer, \& Fischer, 2018), its nominal inclusion with a single chapter in the major handbook for the field (Sawyer, 2014), and its absence in another major international handbook (Fischer, Hmelo-Silver, Goldman, \& Reimann, 2018).

Theories of learning need to be understood, not only within their sociopolitical context but as sociopolitical contexts. Theories of learning have a long legacy of operating to justify existing societal hierarchies through (a) reification, the "tendency to convert abstract concepts [like intelligence] into entities," and (b) the propensity to rank and order "complex variation as a gradual ascending scale" (Gould, 1996; see also Lave, 1996; Martin, 2009). As a field, we systematically fail to address the intersecting histories of eugenics and Western theories of learning and development (Stoskopf, 2002). Invariably, our accounts of the science of learning begins with the seemingly more benign story of behaviorism. The introduction to behaviorism, however, is most often dismembered from its efforts to directly challenge eugenics. Theories of learning are severed from their sociopolitical contexts and consequences through this ritual of scholarly socialization into the Learning Sciences, in turn forming those who are newly initiated into the field and those who do the initiation.

To further illustrate our point, behaviorism, was not just a theory of learning, it was a theory of society so explicitly embodied in John B. Watson's (1924) provocative dispute with the fundamentals of eugenics:

Give me a dozen healthy infants, well-formed, and my own specified world to bring them up in and I'll guarantee to take any one at random and train him to become any type of specialist I might select - doctor, lawyer, artist, merchant-chief, and yes, even beggarman and thief, regardless of his talents, penchants, tendencies, abilities, vocations, and race of his ancestors. (p. 82)

Walden Two (Skinner, 1948) and Beyond Freedom and Dignity (Skinner, 1971) are unequivocal testaments that B.F. Skinner's research on human behavior was tied to a utopian vision of society founded on cultural engineering 
and in direct resistance to eugenics. While Watson's and Skinner's opposition to eugenics might have led them to be more conspicuous and audacious in explicating their theory of learning as a theory of society, this relationship persists, as we expand below, even when researchers do not articulate it (or are aware of it).

For instance, cognitivism and studies of human-machine interaction and decision-making are often interpreted through lenses that obscure their sociopolitical context and consequences. These fields were born out of the pragmatic challenges and needs of World War II to address emergent problems of practice for which behaviorism was inadequate (Lachman, Lachman, \& Butterfield, 1979). These emergent limits of behaviorism included the design of the control panel for a fighter plane, decision making with radars, and performance breakdown when engaged in monitoring sonars for extended durations. As Gardner (1985) elaborates, the war "stimulated" the cognitive revolution. From computer science and the need to analyze large swaths of data, to connections between feedback in engineering devices and homeostatic processes in human nervous system activity discovered by mathematicians working on anti-aircraft machinery, medical practitioners studying people who suffered brain injury from war, and behavior scientists who studied propaganda and the selection of military officers, the war was a boon for cognitive science (Gardner, 1985). Cognitivism and human-machine interaction as we know today may not have taken hold or may have unfolded differently if they had not emerged within the context of World War II. Rooted in the endeavor to tackle the pressing concerns and outcomes of warfare, how have these fields then inevitably entrenched militarism in our society? These are not questions that we can extensively probe within the constraints of this reflection; however, they are questions that we must seriously pursue as a field.

As another example, sociocultural theory materialized within the demands of the Russian Revolution and the need for a new historical, social, and cultural psychology that counteracted the individualism in Western capitalist theories of learning and development (Newman \& Holzman, 2013). It was a theory of learning and development that began to account for, imagine, and strive toward a new society defined by the ideals of the Russian Revolution. It took seriously dialectical and historical materialism. As Cole and Scribner (1978) wrote, Vygotsky sought to "develop a Marxist theory of human intellectual functioning" within the conditions of post-revolutionary Russia, which was the "source of immediate problems facing Vygotsky as well as a source of inspiration" (p. 1). Vygotsky was unequivocal about this enterprise: "I want to find out how science has to be built, to approach the study of the mind having learned the whole of Marx's method" (Cole \& Scribner, 1978, p. 8).

It is not only the origins of a theory that works in concert with associated theories of society. Its uptake, repurposing, and wrangling occur within these contestations. For instance, early English translations of Vygotsky, in the height of the Cold War, "systematically deleted" references to Marxism, and Lenin in particular (Graham, 1993; see also Au, 2007). Even today, Cole and Scribner's (1978) argument or Wertsch's (1988) insight that Vygotsky had a "sincere dedi- 
cation to creating a Marxist analysis of mind" (p. 83) are relegated to forewords, prefaces, and footnotes. We rarely see them genuinely taken up in the Learning Sciences in empirical analyses that use sociocultural theory or in courses that teach Vygotsky. For many in the Learning Sciences, Vygotsky's theories are thereby stripped of its Marxist, revolutionary vision for consumption in capitalist, neoliberal societies.

Theories of learning as social theories is not a phenomenon that we only see through historical hindsight. The work of Kris Gutierrez, Carol Lee, Luis Moll, Michael Cole, Jean Lave, and Ray McDermott (to name a few) made visible that extant theories had constructed and exacerbated ideologies of (in)competency and that new theories of learning could fundamentally upend assumptions about hierarchy in an effort toward new possible worlds (McDermott \& Varenne, 1995). In the same spirit of Vygotsky, their work called for theories of learning that lead to new "imaginations" of society (Gutierrez, 2016) where young people have "dignity" as learners (Espinoza \& Vossoughi, 2014). To be abundantly clear, theories of learning that remain silent about their sociopolitical contexts and consequences are equally political as they reify existing inequities and injustices (Martin, 2009).

Designs and theories of learning do not simply describe existing realities. Our work as researchers of learning also creates, reifies, alters, refines, and transforms the realities that exist (Foucault, 1988; McDermott \& Varenne, 1995; Said, 1979). Viewing theories of learning as theories of society demands that we engage in new lines of inquiry as a field: How do we take stock of and engage with the histories of power that run through the veins of our theories of learning? To what degree have our existing theories of learning contributed to the extreme global environmental threats, ballooning levels of inequality, increased societal polarization, and rising authoritarianism that we are currently experiencing? How do we recognize the sociopolitical contexts in which our work as Learning Scientists takes place today? What are the theories of learning that we need for this political moment with the global rise of nationalism, impending ecological disaster, and the uncertainties of artificial intelligence (Booker, personal communication)? What do we need to study, to "make real" through our research, in order to make our societies more just?

\section{Deepening the Call for Contextuality and Conse- quentiality: Reading Designs and Theories Con- trapuntally}

diSessa and Cobb (2004) urged that "theory must do real design work in generating, selecting and validating design alternatives at the level at which they are consequential for learning" (p.80). We offer an amendment that the metric for consequentiality must include how it matters for learning in society (Jurow \& Shea, 2015; Jurow, Teeters, Shea, \& van Steenis, 2016). To these ends, we propose that, as a field, we more deliberately and systematically read our designs 
and theories contextually, consequentially, and contrapuntally. To read contextually is to account for the political influences and forces, people, and openings that seed designs and theories and allow them to emerge, flourish, or languish. To read consequentially is to consider the possible ramifications of innovations, with an eye toward responsibility (Stilgoe, Owen, \& Macnaghten, 2013), and with the courage for new social and political imaginations (Gutiérrez, 2016). To read contrapuntally, as Said (1993) outlined, means to "to draw out, extend, give emphasis and voice to [the logics of and resistances to empire and imperialism that] are silent or marginally present or ideologically represented" (p. 66) in our designs and theories. Below, we elaborate a contrapuntal approach by reading theories of learning premised on authentic practice in computing education side-by-side with scholarship in sociology that brings the lives of tech industry immigrant workers to the fore.

Our urging to read our designs and theories contrapuntally builds on the opening others have created in the field through their conceptualization of contextuality and consequentiality. We are indebted to how others have theorized fundamental social transformation that is brought about by "creating a significant reorganization of systems of activity in which participants becoming designers of their own futures is an essential aim" (Gutiérrez \& Jurow, 2016, p. 566 ); to work that has sought to make porous the categories of researcher, theorist, and designer in order to allow for new modes of "reciprocity, accountability, and the de-settling of normative hierarchies of power" (Bang \& Vossoughi, 2016, p. 174); and to scholarship that has taken as foundational the need to show how people "learn to navigate and resist disempowering social systems" and "create communities of resilience in the face of challenge" (Lee, 2017, p. x). Complementing and extending these perspectives, we draw on Said's (1993) emphasis that a contrapuntal reading necessitates an explicit juxtaposition to histories and contemporary processes of imperialism - a lens that has not been explicit in these bodies of scholarship.

A sharpened analysis of imperialism distinguishes contrapuntality from contextual and consequential readings. Contrapuntality is not meant to replace either contextuality or consequentiality; it is meant to complement. Imperialism pervades our lives in the form of cultural, political, ideological, economic, and social practices that originally emanated from a metropolitan center in order to govern lives in distant, colonized territories (Said, 1993). Central to the contrapuntal orientation is a vision that therefore "sees Western and non-Western experiences as belonging together because they are connected by imperialism" (Said, 1993, p 279). Said (1993) further argued that imperialism "is supported and perhaps even impelled by impressive ideological formations that include notions that certain territories and people require and beseech domination, as well as forms of knowledge affiliated with domination" (p 9). These histories of domination have largely remained invisible in our theories of and designs for learning (Artiles, 2013).

To concretize contrapuntality, it is helpful to examine an example from Said (1993). As a literary scholar, he analyzed Jane Austen's novel, Mansfield Park. Life at Mansfield Park in England was sustained materially by colonial plan- 
tations on the Caribbean island of Antigua - a fact that is only mentioned in passing in the novel. A contrapuntal reading surfaces the lives and labor of endarkened people, who are both integral to and invisiblized by Mansfield Park. We use the term endarkened to emphasize the dual meaning of people who are constructed as dark and people who are obscured. Our contrapuntal readings in the Learning Sciences similarly ask, "Who is simultaneously integral and invisiblized through imperialism in our conceptualizations of learning?"

To illustrate the value of a contrapuntal lens when examining theories of learning as theories of society, we hone into a prevalent notion of disciplinary authenticity in the Learning Sciences. Our purpose is to illustrate - similar to how theories of learning operated as theories of society in behaviorism, the cognitive revolution, or portrayals of Vygotsky - that these processes continue to exist in central contemporary constructs in the field. We acknowledge an important tradeoff: the focus on a single construct allows us to detail and nuance our argument without simply painting broad strokes about the political nature of learning and its relationship to empire; on the other hand, the deep dive does not leave space for close examinations of other constructs upon which our theories of learning hinge (see Philip, Gupta, Elby, \& Turpen, 2018; The Politics of Writing Collective, 2017; Takeuchi et al., 2020; Sengupta 2020). We hope, however, that our analysis will be an invitation for further consideration of core constructs in our field through a contrapuntal lens.

\section{Computing Education: A Contrapuntal Orienta- tion}

Recently, there has been increased attention to the contextuality and consequentiality of computing education. Thompson's (2019) piece in The New York Times Magazine traced how coding and programming transformed from a lowstatus feminized occupation in the U.S. at the time of its origins to a maledominated lucrative profession in the 1980s. Thompson attributed these changes to cultural shifts in the decade: the increased availability of personal computers along with gendered messages and practices about computing at home; representations of computing in the popular media; a culture of coders working late into the night and paternalistic notions of safeguarding women; and, the use of personality tests to select for "caustic loner qualities" by companies looking to hire programmers. Contextuality is multidimensional and shifts over time. For instance, others have shown that contemporary calls for promoting and diversifying computing (and STEM more broadly) are tied to nation-states advancing their military and economic agendas in a globalized world (Vossoughi \& Vakil, 2018; Philip \& Azevedo, 2017). The push to "broaden participation" in computing frames "underrepresented groups" as untapped human capital, which in turn can counter the threats to "global leadership and domestic security" that arise when the U.S. heavily relies on foreign-born workers (Committee on Equal Opportunities in Science and Engineering, 2013, p. 1). Echoing the nationalist 
post-9/11 agenda, the report "urgently warn[s] that the American way of life is threatened" because of the shortcomings of STEM education (Committee on Equal Opportunities in Science and Engineering, 2013, p. 1). Similarly, the importance of consequentiality in computing - learning that arises from the experiences and concerns of learners and that profoundly shapes the lives of the learners - has been brought to the fore by researchers like Vakil and McKinney de Royston (2019). Given this body of existing work on contextuality and consequentiality, we devote the lion's share of this reflection to developing the lens of contrapuntality.

\section{Theories of Learning Grounded in Authenticity in Com- puting Education}

The emphasis on computing education has become progressively more central over the past three decades, both in the Learning Sciences as well as in K-16 public education (Papert, 1980; diSessa, 2001; Wing, 2006; Sengupta et al., 2013; Guzdial \& du Boulay, 2019). Broadly speaking, two lines of research have emerged in the field. Papert's and diSessa's work focused on empowering children through designing computers and computing platforms (e.g., programming languages and modeling platforms) in ways that are aligned with children's intuitive ways of knowing (Papert, 1980; diSessa, 2001), a tradition that continues largely within the constructionist paradigm (Resnick et al., 2009; Kafai et al., 2014; Wilensky, Brady \& Horn, 2014). A parallel strand of research focused on identifying and scaffolding $\mathrm{K}-16$ students' conceptual challenges with programming in computer science as well as in other STEM disciplines (Sengupta et al., 2013; Guzdial \& du Boulay, 2019). The underlying notion of authenticity that cuts across these lines of work focuses on engaging $\mathrm{K}-16$ learners in representational and epistemic practices that are common to disciplinary experts (Papert, 1972; Wing, 2006; Sengupta et al., 2013). For example, Papert (1972) argued that engaging with LOGO programming can help students think like mathematicians. More recently, Wing's (2006) call for computational thinking is fundamentally premised on notions of authenticity as "thinking processes" used by computer scientists (Sengupta, Farris \& Dickes, 2020). Similarly, Sengupta et al. (2013) and Weintrop et al. (2016) have positioned computational thinking in terms of synergies with epistemic and representational practices in STEM disciplines.

The construction of authenticity, as evident in the previous paragraph, positions professional practice in computing as politically neutral, and similar to Latour (1990) and Pickering (1995), limits its vision within the work of the professionals. Representational and epistemic practices such as modeling, values such as personal meaningfulness, the ability to use the same tools as professionals, and an unproblematic image of the community of practice form the basis of what counts as authentic experiences in computing education. Such views of authenticity obscure the multiple intersecting forms of oppression, including the extraction of labor that necessarily undergirds and defines the reality of these practices in the sphere of this globalized industry. 
It is noteworthy that the Learning Sciences has historically positioned meaningful connections to the self, the discipline, and the "real world" as central to learning in the classroom (Newmann \& Wehlage, 1993; Shaffer \& Resnick, 1999; Engle \& Conant, 2004). In this vein, authenticity envisions how STEM disciplines should be experienced by students in the classroom, by attending to issues of student agency and authority and accountability toward the collective (Engle \& Conant, 2004). Advancing such forms of authenticity in the classroom may however obscure students' cultural repertoires of practice (Gutiérrez \& Rogoff, 2003) unless the epistemological foundations of what should count as productive disciplinary engagement explicitly addresses power and historicity (Agarwal \& Sengupta-Irving, 2019). Here, power is positioned as a "historical and sociopolitical formation that privileges certain forms of knowing (epistemologies) and being (ontologies) over others" (Agarwal \& Sengupta-Irving, 2019; p. 350).

Our concern for contrapuntality builds on Agarwal and Sengupta-Irving's (2019) critique and calls to further expand our understanding of disciplines. We seek analyses that account for the historical and contemporary entanglements between empire and disciplinary practices; further, we urge analyses that counteract current framings of authenticity that make these entanglements invisible. As we begin to see authentic disciplinary work through contrapuntal lenses, the bodies and labor of marginalized and colonized people that make the discipline through being disciplined become visible. The construction of authentic disciplinary practices - practices that render disciplines their essential character - are rooted in the politics of empire; our theories of learning and becoming in the disciplines cannot continue to ignore these realities.

In contrast to seemingly politically neutral and dehistoricized positionings of disciplinary and professional expertise centered on the learners' "selves", critical sociologists present a much more complicated and contested picture of the sociopolitical contexts in which computing professionals are emplaced (Banerjee, 2019; Alegria, 2016). They have argued that the professional context of computing is intrusive and oppressive on immigrant, tech industry workers and their families from endarkened nations. In our analysis, we focus on non-White immigrant workers who are relegated to precarious labor conditions in the U.S. through intersecting processes that include H1B work visa regulations, racism, xenophobia, and the legacies of colonialism and imperialism. The experiences of these immigrant workers must be understood within the broader history of oppression that has been faced and resisted by people of color in U.S. labor markets and public education (Glenn, 2002; Hale, 2016). A contrapuntal orientation toward educational computing cannot ignore these social realities, which we explore in more detail next.

\section{Transnational Migration, Legal Violence and the Work of Coding}

A closer look at the work of sociologists who study the sociopolitical contexts of tech workers in the U.S. reveals the oppressive realities that remain untouched in our educational computing classrooms. For example, Banerjee and Rincon 
(2019) argue that the professional contexts of coding can be understood in light of legal violence on immigrants and their families: "the normalized but cumulatively injurious effects of the law that obstruct and derail immigrants' paths of incorporation" (Menjívar \& Abrego, 2012, pp XX). Banerjee and Rincon (2019) point out that the work of coding is largely done by "highly skilled" immigrants from endarkened nations; although they are rarely viewed as legally vulnerable or as facing limited social and economic opportunities, their lived experiences reveal the daily, micro-interactional and institutional oppressions both at work and at home. As Banerjee and her colleague (Banerjee, 2019; Banerjee and Rincon, 2019) illustrated, these oppressions are direct outcomes of the political and institutional forces that shape and control coding (and more broadly, computing) as a profession.

Striking accounts of workplace segregation were reported by immigrant professionals of color in Banerjee and Rincon's (2019) study. For example, Indian workers were relegated to segregated workspaces where they almost exclusively interacted with other Indian workers, meeting with their U.S. counterparts only once a week during team meetings. Colombian workers were kept from participating in specific projects because their tenure was perceived as only short term. Banerjee and Rincon also found that race and legal status have interlocking effects both inside and outside the workplace. For example, for Colombian workers, their experiences outside the workplace also involved being subject to criminalization "due to the assumption of 'illegality' attached to their race and ethnicity." (Banerjee \& Rincon, 2019, p 28). Furthermore, many of these workers were effectively forced to work for the same company as a result of immigration policies and labor laws that make it nearly impossible to change jobs and difficult to become U.S. permanent residents (Banerjee, 2019). They also reported explicit expectations of unpaid overtime work for immigrant workers (who averaged 12-hour work days), including working on the weekends, during evenings, and holidays - forms of labor that their U.S. colleagues were not expected to do.

Other forms of oppression reached beyond the workplace into their families (Banerjee, 2019). For example, based on federal regulations, most state governments have no legal provisions to provide driver licenses to spouses ("dependents") of these workers. Federal regulations also prohibited work permits for dependents, thereby forcing many of the workers' spouses into illegal forms of self-employment and mental duress from the loss of employability. These intersecting dynamics, the professional expectations at the workplace, coupled with the enactment of U.S. labor and immigration laws, contributed to the creation and exploitation of a patriarchal, gender hierarchy in the families of these workers (Banerjee, 2019). The oppressive gendering and marginalization of the families of immigrant coders from endarkened nations stand in stark contrast to national mandates for increasing gender diversity in computing education in the U.S. (Hill et al., 2010).

So, what happens when we simply present coding as a convivial tool and means for student empowerment in our classrooms? In the most benign form, we rob ourselves of the opportunity to think about the sociopolitical contexts 
in which coding is experienced by professionals, creating a warped view of "who" coders are. We need to position the educational computing classroom as a context for viewing code and coding through intersectional lenses (Collins, 2002) and as lenses that critically analyze translocational positionalities of immigrant workers who actually "do" the work of coding (Anthias, 2012). But the lack of this contrapuntality in the K-16 classrooms and in our field of Learning Sciences research has a significantly more far reaching effect: perpetuating an inequitable and segregated professional practice. As Takeuchi et al. (2020) illustrated, ideologies of workforce readiness and a "skilled technical workforce" that are nationally promoted and guide and fund a significant portion of Learning Sciences research on educational computing (see for example, https://www.nsf .gov/funding/pgm_summ.jsp?pims_id=505006) exacerbate oppressive hierarchies by invoking national security and at least implicitly constructing endarkened people as a perpetual risk and threat.

\section{Theories of Learning in Computing Education as Theories of Society}

In contrast to B.F. Skinner's Walden Two, theories of learning based on authenticity might appear a far cry from being a theory of society. No doubt, there is a difference in explicitness. But, these characteristics are elucidated by our contrapuntal reading. As Artiles (2013) reminds us, a contrapuntal reading challenges "our assumptions about coherence and purity within conceptual models" and provides new insights by putting in conversation bodies of work that are deemed to be distinct, mutually exclusive, or even contradictory. When authentic practice, as it is represented in our field, is read alongside the work of Banerjee and her colleague (Banerjee, 2019; Banerjee \& Rincon, 2019), it becomes clear the notion of disciplinary authenticity is predicated on the erasure of endarkened people in computing. Authentic disciplinary practice as conceived in our field is thus shown to be racialized, gendered, classed, and marked by language and citizenship. Endarkened people in computing are excised from existence in these theories of learning, thus constructing a society where their invisibility is necessarily taken for granted.

While critical approaches that explicitly address the contemporary and emergent sociopolitical contexts and consequences of computing are important, they are not sufficient. There needs to be fundamental shifts in our theories of learning. In this reflection, we have specifically delved into theories of learning that undergird computing as a focus case. There is a degree of uncertainty and unpredictability with this call. But, as we stressed earlier, theories of learning that centered ecological validity and the need to study learning in real-world settings was a courageous shift that the Learning Sciences took at its onset. We're at a parallel juncture today that requires theoretical and methodological boldness to study the real world in its political reality and complexity. Similar to fundamental shifts in our field that have, for example, reframed the learning of mathematics from symbolic manipulation to "modifying and extending one's discourse" (Sfard, 2007), our emergent theories of learning need to boldly 
co-emerge through commitments of justice and solidarity with endarkened people. Analogous to the discursive turn in the learning of disciplines, justice and solidarity through a contrapuntal lens are not simply external relational aspirations; our approaches to understanding learning must take historical and contemporary processes of imperialism into account and allow us to newly and imaginatively conceive of solidarity as co-constructing the disciplines themselves in fundamentally new ways (Philip \& Gupta, 2020).

As we described earlier, we intentionally focused on authenticity as professional practice to allow for depth and nuance without simply painting broad strokes about theories of learning as theories of society; however, the fundamental argument we make applies to how we, as a field, have conceived of learning across multiple domains. For instance, learner-centered positionings of authenticity in computing education (Papert, 1980; diSessa, 2000; Guzdial, 2015) focused on learners' intuitions and prior knowledge. Yet, the focus on learners' selves precluded substantive engagement with the realms of oppression that makes the associated professional practices possible. As another example, the recent uptake of epistemic injustice in the Learning Sciences (e.g. Barzilai \& Chinn, 2018; Miller et al., 2018) employs a relatively individualistic lens. The uptake of this framework does not deeply engage the imperial roots of epistemic violence (e.g. Bourdieu \& Passerson, 1990) or consider the ways in which the labor of endarkened peoples are entangled with disciplines and professions (e.g. Glenn, 2002). As a field, we simply lack theories of learning that seriously engage the historical and contemporary processes of imperialism and their profound consequences on the lives, labor, and longings of endarkened peoples.

We hope that our field's theories of learning will move toward a profound recognition and unrelenting effort to center the full humanity of endarkened people. A contrapuntal lens brings to the fore endarkened people who has been invisiblized in the largely U.S.-centric and Western European-centric field of the Learning Sciences. Given that our field has emerged in these imperial metropoles, such silences are unsurprising. How, if at all, might the work of Learning Scientists take into account and become responsive to the histories of empire and contemporary processes that have shaped the lives of colonized peoples and their diasporas? We hope that the lens of empire and imperialism might provide an intersectional analysis with emerging scholarship in the Learning Sciences that brings into focus a critical examination of race (Pham \& Philip, 2020; Philip, Olivares-Pasillas, \& Rocha, 2016), anti-Blackness (Davis \& Schaeffer, 2019; McKinney de Royston \& Nasir, 2017), settler colonialism (Bang \& Marin, 2015), and cisheteronormativity (Paré, Shanahan, \& Sengupta, 2020; Uttamchandani, in press). As a starting point, learning in the disciplines is to be in solidarity with people who do disciplinary work, and more importantly, with people whose labor is hidden through the mechanisms of imperialism while making disciplinary work possible. Learning, from this perspective, is not only reflected in our increased capacity to participate in the representational and epistemic practices of scientists or technologists. Rather, learning becomes defined by our ability to grow in solidarity with the experiences and struggles of endarkened people. In such a view of learning, the discipline becomes more 
authentically conceived in its sociopolitical fullness. This is, at once, an ontological, epistemological and axiological broadening and deepening of what should count as authenticity in our theories of learning, and it implies that solidarity with endarkened people - not the capital of production - is what we have potential to create when we learn. Possibilities of contrapuntal solidarity in the Learning Sciences, within the context of computing and authenticity would include designing learning environments to name, ameliorate, address, interrupt, and re-envision the practices of confinement and erasure of endarkened people whose labor constitutes the discipline.

\section{Concluding Thoughts: Contrapuntal Challenges to Authenticity}

We began this reflection by stressing that all designs and theories of learning are implicit theories of society. We argued that our field must do more to understand theories of learning as emergent within the contradictions and tensions of researchers' cultural and sociopolitical contexts. We contended that theories of learning are also consequential for the worlds we then collectively construct. To ground these larger principles in the pragmatics of everyday learning, we closely examined the contemporary push for disciplinary authenticity in computing education. Delving into this aspect of contemporary educational computing reveals how the social construction of disciplinary and professional expertise in computing is intricately interwoven with historically persistent patterns of the appropriation of lives and labor of endarkened people through systems of transnational migration and institutional forms of racial segregation.

As we begin to see disciplinary work (broadly speaking) in light of contrapuntal orientations, we will begin to recognize the bodies that make the discipline by becoming disciplined. Our theories must carry the burden of this recognition, and our pedagogies must work to create conditions for restoration and more just futures. The questions we raise are profoundly ontological: should we continue to advance imperialist enframings of disciplines in the guise of authenticity? What, then, should count as disciplinary authenticity from a contrapuntal perspective? We stress, again, that we might not be able to predict what will unfold with new theories and methods. But in its origin, our field was willing to take that risk of moving from the laboratory to the classroom (Brown, 1992), with all its uncertainties and potential perils. Nearly three decades later, we echo Ann Brown's words from the second volume of this journal: "Learning theory has undergone major modifications even within [...] the last 20 years, and methodological changes are needed to reflect these developments" (Brown, 1992, p. 144). We are aware that our call for deepening the political turn in the Learning Sciences is not without contention and is subject to the critiques that surprisingly parallel the very criticisms that were (and are) mounted against design-based research. But we are also encouraged by Brown's uncanny prescience that cautioned that researchers of learning are "creatures of their time, 
and the methods they use to attack such durable problems as learning must be reconsidered in light of theory change" (p. 144). It is abundantly clear that the political nature and realities of our worlds and the learning within them are inseparable; the question before us is how our field takes up this persistent challenge that has certainly defined our field from its very beginning.

\section{Acknowledgment}

We thank the Political and Ethical Learning Virtual Lab faculty, Pallavi Banerjee, and Suraj Uttamchandani for reading early drafts of this manuscript and for providing valuable suggestions, comments, and critiques. Partial funding for this work was provided by NSF-DRL 1842358. All opinions expressed are the authors' and not endorsed by funding agencies.

\section{References}

Alegria, S. N. (2016). A Mixed Methods Analysis of the Intersections of Gender, Race, and Migration in the HighTech Workforce. [Doctoral dissertation, University of Massachusetts at Amherst]. Retreived from: https://scholarworks. umass.edu/dissertations_2/614/

Anthias, F. (2012). Transnational mobilities, migration research and intersectionality. Nordic Journal of Migration Research, 2, 102-110.

Artiles, A. J. (2013). Untangling the racialization of disabilities: An intersectionality critique across disability models. DuBois Review, 10, 329-347.

Banerjee, P. (2019). Subversive self-employment: Intersectionality and selfemployment among dependent visas holders in the United States. American Behavioral Scientist, 63(2), 186-207.

Banerjee, P., \& Rincón, L. (2019). Trouble in tech paradise. Contexts, 18(2), 24-29.

Bang, M., \& Vossoughi, S. (2016). Participatory design research and educational justice: Studying learning and relations within social change making. Cognition \& Instruction, 34(3), 173-193.

Barzilai, S. \& Chinn, C.A. (2018) On the goals of epistemic education: Promoting apt epistemic performance, Journal of the Learning Sciences, 27(3), 353-389.

Booker, A., Vossoughi, S., \& Hooper, P. (2014, June). Tensions and possibilities for political work in the learning sciences. Paper presented to the International Conference of the Learning Sciences, Boulder, CO. 
Brown, A.L. (1992) Design experiments: Theoretical and methodological challenges in creating complex interventions in classroom settings, The Journal of the Learning Sciences, 2(2), 141-178.

Cobb, P., Confrey, J., diSessa, A., Lehrer, R., \& Schauble, L. (2003). Design experiments in educational research. Educational Researcher, 32(1), 9 13.

Collins, P. H. (2002). Black feminist thought: Knowledge, consciousness, and the politics of empowerment. New York, NY: Routledge.

Committee on Equal Opportunities in Science and Engineering. (2013). 20112012 Biennial report to Congress. Arlington, VA: National Science Foundation.

diSessa, A. A. (2001). Changing minds: Computers, learning, and literacy. MIT Press.

diSessa, A.A. \& Cobb, P. (2004). Ontological innovation and the role of theory in design experiments. Journal of the Learning Sciences, 13(1), 77-103.

Fischer, F., Hmelo-Silver, C., Goldman, S., \& Reimann, P. (Eds.) (2018). International handbook of the Learning Sciences. New York, NY: Routledge.

Fishman, B. J., Penuel, W. R., Allen, A.-R., Cheng, B. H., \& Sabelli, N. (2013). Design-based implementation research: An emerging model for transforming the relationship of research and practice. In B. J. Fishman \& W. R. Penuel (Eds.), National Society for the Study of Education: Vol 112. Design Based Implementation Research (pp. 136-156).

Foucault, M. (1988). Madness and civilization: A history of insanity in the age of reason. New York, NY: Random House.

Glenn, E. N. (2004). Unequal Freedom: How Race and Gender Shaped American Citizenship and Labor. Harvard University Press.

Gould, S.J. (1996). The mismeasure of man. New York, NY: W.W. Norton \& Company.

Gutiérrez, K. D., \& Jurow, A. S. (2016). Social design experiments: Toward equity by design. Journal of the Learning Sciences, 25(4), 565-598.

Gutiérrez, K.D. (2016). Designing resilient ecologies: Social design experiments and a new social imagination. Educational Researcher, 45(3), 187-196.

Gutiérrez, K.D. \& Rogoff, B. (2003). Cultural Ways of Learning: Individual 
Traits or Repertoires of Practice. Educational Researcher, 32(5), 19-25.

Guzdial, M. (2015). Learner-centered design of computing education: Research on computing for everyone. Morgan \& Claypool Publishers.

Guzdial, M., \& du Boulay, B. (2019). The History of Computing Education Research. In S. A. Fincher \& A. V. Robins (Eds.) The Cambridge Handbook of Computing Education Research. Cambridge, UK: Cambridge University Press, 11-39.

Hale, J. N. (2016). The freedom schools: Student activists in the Mississippi civil rights movement. Columbia University Press.

Hill, C., Corbett, C., \& St Rose, A. (2010). Why so few? Women in science, technology, engineering, and mathematics. American Association of University Women. 1111 Sixteenth Street NW, Washington, DC.

Hostetler, A., Sengupta, P., \& Hollett, T. (2018). Unsilencing Critical Conversations in Social-Studies Teacher Education using Agent-based Modeling. Cognition and Instruction, 36(2), 139-170.

International Society of the Learning Sciences. (n.d.). Retrieved fromhttp: //www.isls.org/

Jurow, A.S. \& Shea, M. (2015). Learning in equity-oriented scale-making projects. Journal of the Learning Sciences, 24(2), 286-307.

Jurow, A.S., Teeters, L., Shea, M., \& Van Steenis, E. (2016). Extending the consequentiality of "invisible work" in the food justice movement. Cognition \& Instruction 34(3), 210-221.

Kafai, Y. B., Lee, E., Searle, K., Fields, D., Kaplan, E., \& Lui, D. (2014). A crafts-oriented approach to computing in high school: Introducing computational concepts, practices, and perspectives with electronic textiles. $A C M$ Transactions on Computing Education (TOCE), 14(1), 1-20.

Lachman, R., Lachman, J.L., \& Butterfield, E.C. (1979). Cognitive psychology and information processing: An introduction. New York, NY: Psychology Press.

Lave, J. (1996). Teaching, as learning, in practice. Mind, Culture, and Activity, 3(3),149-164.

Lee, C. D. (2017). Forward: Critical learning opportunities for the Learning Sciences. In I. Esmonde \& A. N. Booker (Eds.), Power and privilege in the Learning Sciences: Critical and sociocultural theories of learning (pp. vii-xii). New York, NY: Routledge. 
Martin, D. B. (2009). Researching race in mathematics education. Teachers College Record, 111 (2), 295-338.

McDermott, R., \& Varenne, H. (1995). Culture "as" disability. Anthropology \& Education Quarterly, 26, 324-348.

McKinney de Royston, M. \& Sengupta-Irving, T. (2019). Another step forward: Engaging the political in learning. Cognition \& Instruction. Advance online publication.

McKinney de Royston, M., \& Nasir, N. (2017). Racialized Learning Ecologies: Understanding Race as a Key Feature of Learning and Developmental Processes in Schools. In N. Budwig, E. Turiel, \& P. Zelazo (Eds.), New Perspectives on Human Development (pp. 258-286). Cambridge: Cambridge University Press.

Menjívar, C., \& Abrego, L. (2012). Legal violence: Immigration law and the lives of Central American immigrants. American Journal of Sociology, 117, 1380-1421.

Miller, E, Manz, E, Russ, R, Stroupe, D, Berland, L. (2018). Addressing the epistemic elephant in the room: Epistemic agency and the next generation science standards. Journal of Research in Science Teaching, 55, 1053-1075.

Nathan, M. J., Rummel, N., \& Hay, K. E. (2016). Growing the learning sciences: Brand or big tent? Implications for graduate education. In M. A. Evans, M. J. Packer, \& R. K. Sawyer (Eds.), Reflections on the learning sciences (pp. 191-209). Cambridge, UK: Cambridge University Press

Newmann, F. M., \& Wehlage, G. G. (1993). Five standards of authentic instruction. Educational Leadership, 50(7), 8-12.

Newman, F. \& Holzman, L. (2013). Lev Vygotsky: Revolutionary scientist. New York, NY: Psychology Press.

Packer, M. J., \& Maddox, C. (2016). Mapping the territory of the learning sciences. In M. A. Evans, M. J. Packer, \& R. K. Sawyer (Eds.), Reflections on the learning sciences (pp. 126-154). Cambridge, UK: Cambridge University Press.

Papert, S. (1972). Teaching children to be mathematicians versus teaching about mathematics. International Journal of Mathematical Education in Science and Technology, 3(3), 249-262.

Papert, S. (1980). Mindstorms: Children, computers, and powerful ideas. Basic Books, Inc.

To appear in: Journal of the Learning Sciences 
Paré, D., Shanahan, M-C. \& Sengupta, P. (2020). Queering Complexity Using Multi-Agent Simulations. In M. Gresalfi \& L. Horn (Eds.), Interdisciplinarity in the Learning Sciences, 14th International Conference of the Learning Sciences (ICLS), (pp. 1397 - 1404). London: International Society of the Learning Sciences.

Pham, J.H. \& Philip, T.M. (2020). Shifting education reform towards antiracist and intersectional visions of justice: A study of pedagogies of organizing by a teacher of color. Journal of the Learning Sciences. Advanced online publication: 10.1080/10508406.2020.1768098

Philip, T.M. (2019). Principled improvisation to support novice teacher learning. Teachers College Record, 121(6).

Philip, T.M. \& Azevedo, F. S. (2017). Everyday science learning and equity: Mapping the contested terrain. Science Education, 101(4), 526-532.

Philip, T.M., Bang, M., Jackson, K. (2018). Articulating the "how," the "for what," the "for whom," and the "with whom" in concert: A call to broaden the benchmarks of our scholarship. Cognition and Instruction, 36(2), 83-88.

Philip, T.M. \& Gupta, A. (2020). Emerging perspectives on the co-construction of power and learning in the Learning Sciences, mathematics education, and science education. Review of Research in Education, 44, 195-217.

Philip, T.M., Gupta, A., Elby, A., \& Turpen, C. (2018). Why ideology matters for learning: A case of ideological convergence in an engineering ethics classroom discussion on drone warfare. Journal of the Learning Sciences, 27(2), 183-223.

Philip, T.M., Olivares-Pasillas, M. C., \& Rocha, J. (2016). Becoming racially literate about data and data literate about race: A case of data visualizations in the classroom as a site of racial-ideological micro-contestations. Cognition and Instruction, 34 (4), 361-388.

Resnick, M., Maloney, J., Monroy-Hernández, A., Rusk, N., Eastmond, E., Brennan, K., ... \& Kafai, Y. (2009). Scratch: programming for all. Communications of the ACM, 52(11), 60-67.

Said, E. (1979). Orientalism. New York, NY: Vintage Books.

Said, E. (1993). Culture and imperialism. New York, NY: Vintage Books.

Sandoval, S. (2014). Conjecture mapping: An approach to systematic educational design research. Journal of the Learning Sciences, 23(1),18-36. 
Sawyer, R.K. (Ed.) (2014). The Cambridge handbook of the Learning Sciences (2nd edition). Cambridge, U.K.: Cambridge University Press.

Sengupta, P., Kinnebrew, J. S., Basu, S., Biswas, G., \& Clark, D. (2013). Integrating computational thinking with $\mathrm{K}-12$ science education using agent-based computation: A theoretical framework. Education and Information Technologies, 18(2), 351-380.

Sengupta, P., Dickes, A., \& Farris, A. V. (2020). Voicing code in STEM: A dialogical imagination. MIT Press.

Sengupta, P. (2020, June). Re-orienting design: An unbearable pain. In V. Hand, S. Vossoughi and S. Jurow (Co-Chairs), Special Session (Identity \& Learning Strand), International Conference of the Learning Sciences (ICLS 2020). ISLS, Nashville, TN. Retrieved from: http://hdl.handle.net/1880/112215

Sfard, A. (2007) When the rules of discourse change, but nobody tells you: Making sense of mathematics learning from a commognitive standpoint. Journal of the Learning Sciences, 16(4), 565-613.

Shavelson, R. J., Phillips, D. C., Towne, L., \& Feuer, M. J. (2003). On the science of education design studies. Educational Researcher, 32(1), 25-28.

Skinner, B.F. (1948). Walden two. Indianapolis, IN: Hackett Publishing Company, Inc.

Skinner, B.F. (1971). Beyond freedom and dignity. Indianapolis, IN: Hackett Publishing Company, Inc.

Sommerhoff, D., Szameitat, A., Vogel, F., Chernikova, O., Loderer, K., and Fischer, F. (2018) What do we teach when we teach the Learning Sciences? A document analysis of 75 graduate programs. Journal of the Learning Sciences, 27(2), 319-351.

Stilgoe, J., Owen, R., \& Macnaghten, P. (2013). Developing a framework for responsible innovation. Research Policy, 42, 1568-1580.

Stoskopf, A. (2002) Echoes of a forgotten past: Eugenics, testing, and education reform. The Educational Forum, 66(2), 126-133.

Takeuchi, M. A., Sengupta, P., Shanahan, M. C., Adams, J. D., \& Hachem, M. (2020). Transdisciplinarity in STEM education: a critical review. Studies in Science Education, 56(2),213-253. DOI: 10.1080/03057267.2020.1755802.

The Politics of Learning Writing Collective. (2017). The learning sciences in a new era of U.S. Nationalism. Cognition and Instruction, 35(2), 91-102. 
Thompson, C. (2019, February 13). The secret history of women in coding. The New York Times Magazine.

Uttamchandani, S. (in press). Educational intimacy: Learning, prefiguration, and relationships in an LGBTQ+ youth group's advocacy efforts. Journal of the Learning Sciences.

Vakil, S \& McKinney de Royston, M. (2019) Exploring politicized trust in a racially diverse computer science classroom. Race Ethnicity and Education, 22(4), 545-567.

Vossoughi, S., \& Vakil, S. (2018). Towards what ends? A critical analysis of militarism, equity and STEM education. In A. Ali \& T. L. Buenavista (Eds.), At War!: Challenging Racism, Materialism, and Militarism in Education. New York, NY: Fordham University Press.

Watson, J. B. (1924). Behaviorism. New York, NY: People's Institute.

Weintrop, D., Beheshti, E., Horn, M., Orton, K., Jona, K., Trouille, L., \& Wilensky, U. (2016). Defining computational thinking for mathematics and science classrooms. Journal of Science Education and Technology, 25(1), 127-147.

Wilensky, U., Brady, C. E., \& Horn, M. S. (2014). Fostering computational literacy in science classrooms. Communications of the ACM, 57(8), 24-28.

Wing, J. M. (2006). Computational thinking. Communications of the ACM, 49(3), 33-35.

To appear in: Journal of the Learning Sciences 